\title{
Age and Growth of the Bull Shark, Carcharhinus leucas, from Southern Gulf of Mexico
}

\author{
A. Cruz-Martínez ${ }^{1}$ \\ Institute of Marine Sciences and Limnology, National Autonomous University of Mexico \\ Ciudad Universitaria, 04510 México D.F. \\ X. Chiappa-Carrara ${ }^{2}$ \\ Marine Ecology Research Unit, FES-Z, National Autonomous University of Mexico \\ and \\ V. Arenas-Fuentes ${ }^{3}$ \\ Institute of Marine Sciences and Limnology, National Autonomous University of Mexico, \\ Ciudad Universitaria, 04510 México D.F.
}

Cruz-Martínez, X. Chiappa-Carrara, V. Arenus-Fuentes. 2005. Age and Growth of the Bull Shark, Carcharhinus leucas, from Southern Gulf of Mexico. J. Northw. Att. Fish. Sci., 35: 367-374. doi:10.2960/J.v35.m481

\begin{abstract}
Age and growth of bull shark, Carcharhinus leucas, was investigated in the southern Gulf of Mexico (Veracruz and Campeche, Mexico) from December 1993 through June 1997. Ninety-five specimens were obtained from commercial fishery catches, and vertebrae were examined from 20 males, 61 females and 14 individuals unidentified to sex. Vertebrae were examined using five different techniques to enhance the visibility of growth rings: i) alizarin red stain, ii) crystal violet stain, iii) $\mathrm{X}$-ray, iv) silver nitrate stain, and $\mathrm{v}$ ) without staining. Verification of temporal growth ring formation was done by the indirect method of marginal increment analysis. An isometric relationship was found between growth and length of centrum, is described by a linear equation. Age-at-maturity was 10 years (204 cm total length, TL) for females and 9-10 years (190-200 cm TL) for males. The oldest female was $28(256.0 \mathrm{~cm} \mathrm{TL})$, and the oldest male was $23(243.0 \mathrm{~cm} \mathrm{TL})$. The von Bertalanffy growth parameters were estimated for the species $\left(L_{\infty}=256.4 \mathrm{~cm} \mathrm{TL}, k=0.1397\right.$ per year and $t_{0}$ $=-1.935)$, for males $\left(L_{\infty}=248.4 \mathrm{~cm} \mathrm{TL}, k=0.1692\right.$ per year and $\left.t_{\mathrm{o}}=-1.03\right)$, and for females $\left(L_{\infty}=\right.$ $262.1 \mathrm{~cm} \mathrm{TL}, k=0.1235$ per year and $\left.t_{\mathrm{o}}=-2.44\right)$. Sexual differences for each particular growth curve were found, $L_{\infty}$ being the parameter that showed the greatest difference between males and females; females attain a larger size.
\end{abstract}

Key words: Age, ageing methods, Carcharhinus leucas, growth, length maturity, vertebrae

\section{Introduction}

In the Gulf of Mexico, 33 main species of sharks are commercially exploited (30 000 tons). The sixth most important by volume captured (approximately, 700 tons) is the bull shark, Carcharhinus leucas, contributing $2 \%$ of the catch in the region (Rodríguez de la Cruz et al., 1996). This is a coastal, estuarine, riverine and lacustrine shark usually found near-shore in marine habitats. This species has a widespread distribution along the continental coast of all tropical and subtropical seas, and travels far up warm rivers into freshwater lakes (Compagno, 1984). Although information on its freshwater biology is documented by
Thorson et al. (1966) and Thorson (1971; 1972), information on age and growth data are scarce (Thorson and Lacy, 1982; Branstetter and Stiles, 1987). In this paper, age and growth of the C. leucas from the southern Gulf of Mexico are reported to further contribute to the knowledge on the population dynamics.

\section{Materials and Methods}

Bull sharks $(n=95)$ were obtained from the commercial fishery catches in coastal and shelf waters of Veracruz and Campeche, Mexico, from December 1993 through June 1997. Total length (TL, $\pm 0.5 \mathrm{~cm})$ of individuals was

\footnotetext{
1 Present address: School of Biological Sciences, University of East Anglia, Norwich NR4 7TJ, England

2 Present address: Unidad Académica Sisal, Sisal, Yucatán, National Autonomous University of Mexico

3 Present address: Ecology and Fisheries Center, Universidad Veracruzana
} 
measured as the straight-line distance between perpendiculars from the snout to the tip of the caudal fin with the caudal fin in a natural position (Branstetter and Stiles, 1987). Maturity of males and females was determined using morphological and gonadal characteristics (for males the degree of clasper calcification and rotation; for females the uterine development, presence of developing or ripe ovarian eggs or presence of uterine embryos).

For age and growth analyses, a section of the vertebral column was removed from under the first dorsal fin. Vertebrae were then preserved in 70\% isopropyl alcohol (Branstetter and McEachran, 1986). Individual centra were submersed in a $5.25 \%$ solution of sodium hypochlorate for 10-40 minutes (Wintner and Cliff, 1996) to facilitate the mechanical removal of the neural arch, apophysis and remaining connective tissue. A sagittal section was cut from centrum with an Isomet saw equipped with a diamond-bordered blade. Thin laminae (thickness $0.4 \pm 0.1 \mathrm{~cm}$ ) were obtained and mounted on glass microscope slides with clear epoxy resin for viewing under transmitted light.

\section{Ring-enhancing methods}

Vertebrae having $<15$ bands could be counted without any staining technique but those with a greater number of rings presented some problems. In these cases, five methods to enhance visibility of growth rings were tested: i) alizarin red stain, ii) crystal violet stain, iii) X-rays, iv) silver nitrate stain, and v) without staining. The alizarin red method proved to be a simple way to enhance the rings.
Distinct marks (annuli), as illustrated by Bransttetter and Stiles (1987) were visible in the intermedialia of the centra (Fig. 1). A growth ring was defined as a pair of opaque (more mineralized) and translucent bands. To confirm that all the vertebrae from one animal have the same number of rings, complete vertebral columns from two specimens (from one male and one female) were analyzed. The number of rings on every fifth vertebra was counted. Preliminary results showed that the number of rings was the same throughout the vertebral column $(P>0.05)$ and that the best vertebrae to use for age determination were the ones located under the first dorsal fin, since their radius has the greatest magnitude (Fig. 2).

\section{Ring counts}

Three non-consecutive counts, in which the reader had no knowledge of the identity or characteristics of specimens, were made. The average percentage error index (APE, Beamish and Fournier, 1981) was used as an estimate of count reproducibility. An upper limit in the APE was set at $20 \%$ for each vertebra (Wintner and Cliff, 1996). Samples were not included in the analysis if, after a fourth count, they were above this limit. Final age estimates were the average of at least three readings.

\section{Centrum analysis}

The radius of each centrum was measured from the focus to the distal margin of the corpus calcareum under a binocular dissecting microscope equipped with an ocular micrometer, and the radius was then related to TL through linear regression analysis (Killam and Parsons, 1989).

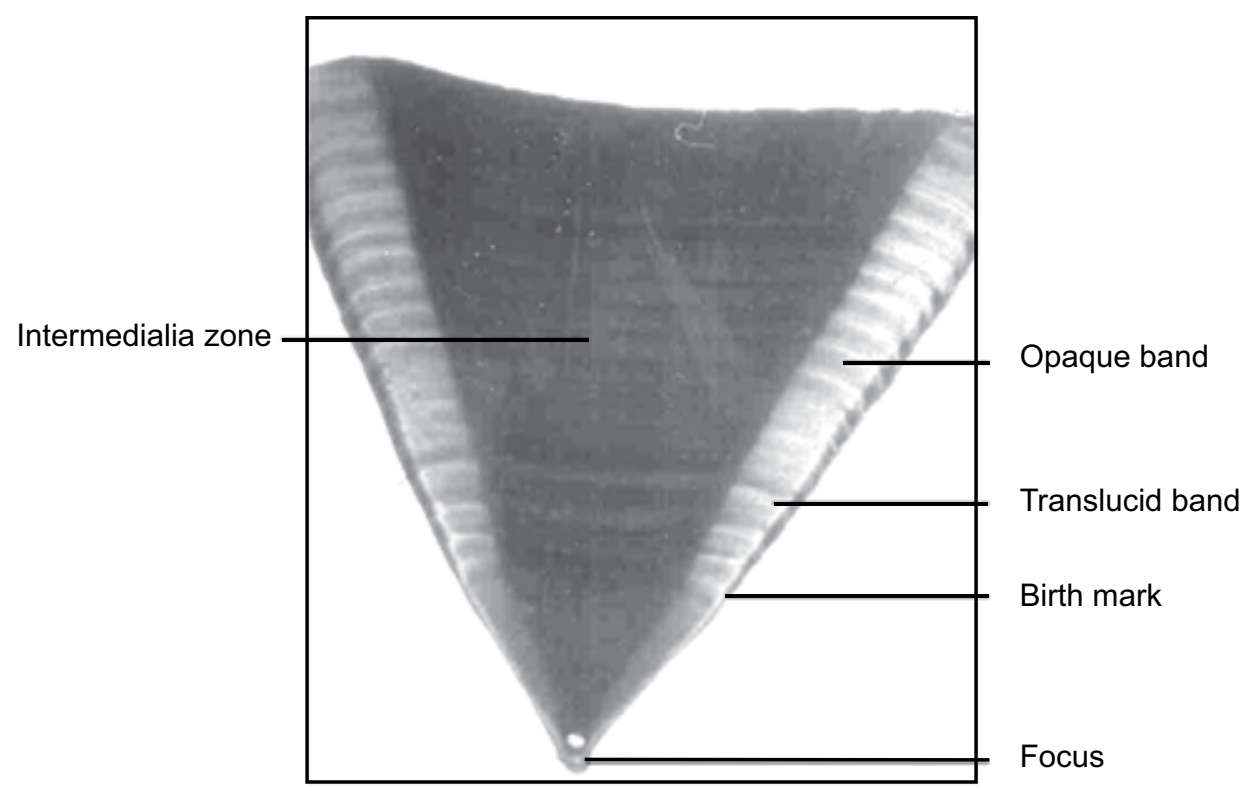

Fig. 1. One half of a sagittal section of a centrum of bull shark, Carcharhinus leucas, showing the growth marks used to estimated ages. 


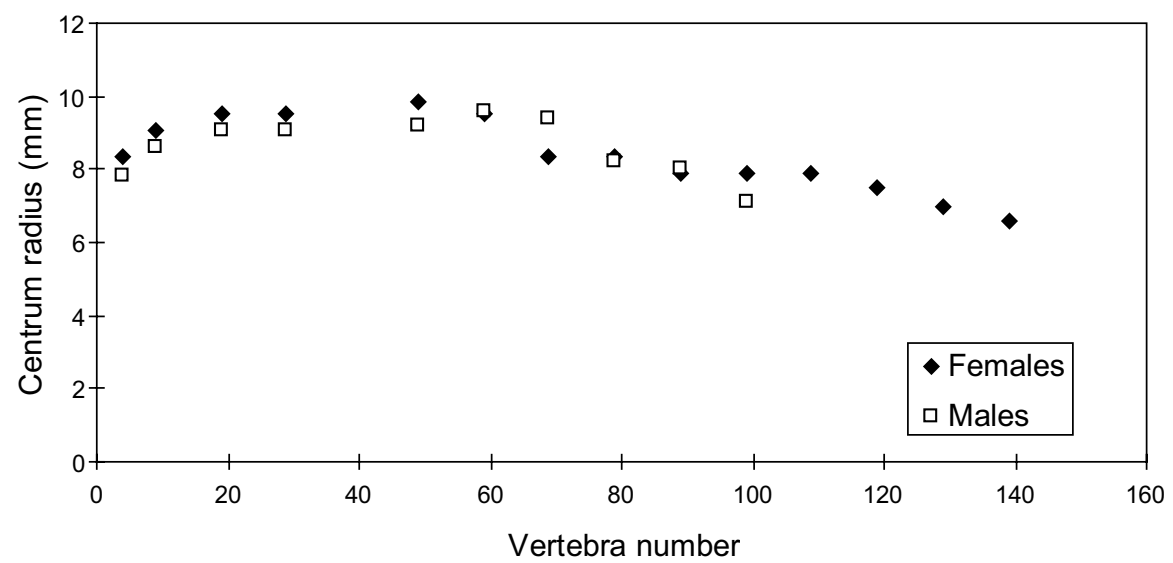

Fig. 2. Centrum radius at different locations along the vertebral column of bull shark, Carcharhinus leucas, from the southern Gulf of Mexico

Differences between regression lines of data belonging to males and females were tested with an analysis of covariance (Zar, 1999). The periodicity of the formation of the rings was assessed by examining the margins of vertebrae using the marginal increment analysis (MI) calculated by the following equation (Chen et al., 1990; Galluci et al., 1996; Kwang-Ming et al., 1998):

$$
M I=\frac{R-r_{b}}{r_{b}-r_{b-1}}
$$

where $R$ is the centrum radius, and $r_{\mathrm{b}}$ and $r_{b-1}$ are the radii of the last and one before the last annuli, respectively. Time-series of monthly MI data was analyzed using a third order polynomial smoothing to obtain the time of annulus formation.

\section{Growth}

The von Bertalanffy growth model was fitted with a computerized algorithm (FISHPARM; Prager et al., 1987) using observed age-length data (11 data for males and 42 data for females, respectively; Table 1). Hotelling's $T^{2}$ test (Bernard, 1981) was used to compare growth curves of the two sexes. This test assumes that estimations of $L_{\infty}, k$ and $t_{\mathrm{o}}$ for both groups (males and females) were obtained from two normal distributions of joint probability with three variables and one common variance.

\section{Results}

The length distribution of the bull shark Carcharhinus leucas captured during the sampling period is shown in Fig. 3. Three main modes can be observed: the first one includes individuals $\leq 131.5 \mathrm{~cm} \mathrm{TL}$, the second includes the range 159.6 to $\leq 285.5 \mathrm{~cm} \mathrm{TL}$, and the last one, individuals $\geq 313.6 \mathrm{~cm} \mathrm{TL}$.
Vertebrae of 20 males, 61 females, and 14 specimens unidentified to sex were analysed, included 3 embryos. Exact agreement of ring counts was reached on $70 \%$ of readings. The $2.37 \%$ APE indicated that aging had a relatively high level of precision. Age estimates ranged from 5 to 23 years in males of C. leucas (TL range 165-254 cm), and from 4 to 28 years in females $(174-271 \mathrm{~cm})$. This information was used to calculate von Bertalanffy parameters (Table 1), for these analyses, embryo data were not used.

The relationship between centrum radius ( $\mathrm{mm}$ ) and TL was linear. Since no differences in the regression lines of sexes were detected $(P>0.05)$, data were pooled and the following equation was calculated:

$$
T L=14.42 X+28.43\left(n=75 ; r^{2}=0.89\right)
$$

where $X=$ centrum radius.

Monthly analysis of MI data is shown in Fig. 4. Polynomial smoothing showed that MI values have a peak in early spring, while low values are present in the fall suggesting that band deposition takes place at this time of the year, verifying the annual periodicity of bands. Apparently, the annulus is formed at birth since unborn sharks did not have an embryonic mark.

In Fig. 5, growth curves of C. leucas, as described by the von Bertalanffy growth model fit with observed data (Table 1), are shown.

Table 2 contains the values of the growth parameters, their standard errors, and coefficients of variation calculated with the Prager et al., (1987) method for both sexes and population. The results of the multivariate 
TABLE 1. Age-length (TL, cm) relationship of the bull shark, Carcharhinus leucas, from the southern Gulf of Mexico. Standard deviations (SD) and sample size (n) are shown.

\begin{tabular}{|c|c|c|c|c|c|c|}
\hline \multirow[b]{2}{*}{ Age-group } & \multicolumn{3}{|c|}{ Males } & \multicolumn{3}{|c|}{ Females } \\
\hline & Total length $(\mathrm{cm})$ & SD & $n$ & Total length $(\mathrm{cm})$ & SD & $n$ \\
\hline embryo & 39.0 & 12.7 & 2 & 55.0 & & 1 \\
\hline 4 & & & & 174.0 & & 1 \\
\hline 5 & 165.0 & & 1 & & & \\
\hline 7 & 174.0 & & 1 & 185.5 & 13.4 & 2 \\
\hline 8 & 201.0 & & 1 & & & \\
\hline 9 & 206.0 & & 1 & 196.8 & 6.3 & 5 \\
\hline 10 & & & & 201.3 & 15.1 & 3 \\
\hline 11 & & & & 209.7 & 9.5 & 6 \\
\hline 13 & & & & 215.6 & 16.7 & 4 \\
\hline 14 & 223.0 & 12.7 & 2 & & & \\
\hline 16 & & & & 219.0 & & 1 \\
\hline 17 & & & & 226.8 & 10.0 & 5 \\
\hline 18 & 234.0 & & 1 & & & \\
\hline 19 & 237.0 & & 1 & & & \\
\hline 20 & 241.0 & 4.2 & 2 & 238.8 & 15.1 & 4 \\
\hline 22 & & & & 247.3 & 22.5 & 3 \\
\hline 23 & 254.0 & & 1 & 253.67 & 21.1 & 3 \\
\hline 25 & & & & 256.0 & 1.4 & 2 \\
\hline 26 & & & & 265.0 & & 1 \\
\hline 28 & & & & 271.0 & 8.5 & 2 \\
\hline
\end{tabular}

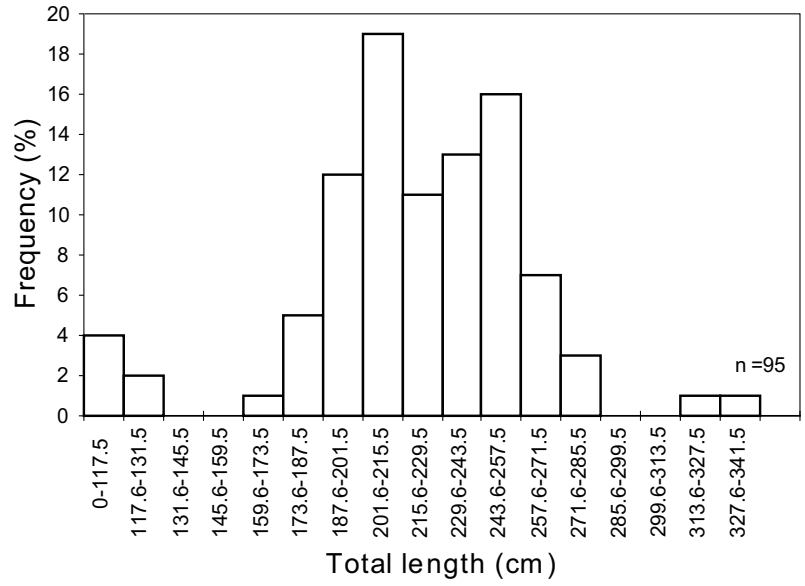

Fig. 3. Length distribution of 95 bull sharks, Carcharhinus leucas, sampled in the southern Gulf of Mexico December 1993-June 1997.

analysis show that males and females grow differently. The calculated $T^{2}$ value is significant $(P<0.05) . L_{\infty}$ is the parameter that showed the highest differences between sexes (Table 3).

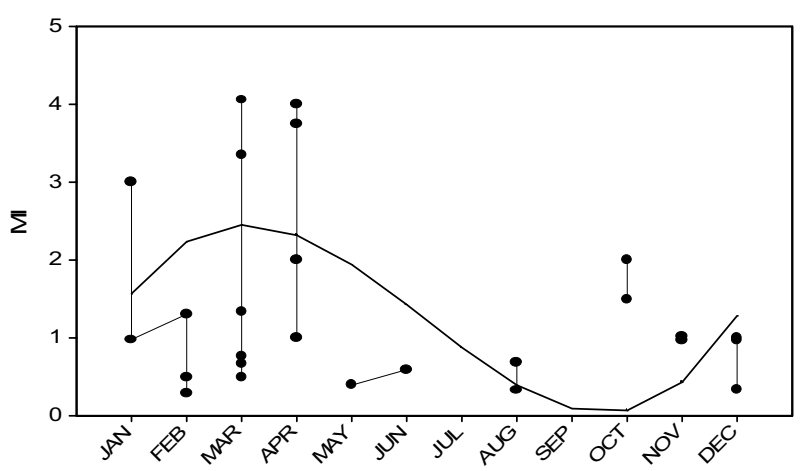

Fig. 4. Monthly analysis of Marginal Increment (MI) data for bull shark, Carcharhinus leucas, from the southern Gulf of Mexico. - Third order polynomial fit.

Age at maturity was 10 years $(204 \mathrm{~cm} \mathrm{TL})$ for females and 9-10 years (190-200 cm TL) for males. Growth rates of C. leucas are high during the first ten years of life, until males and females reach sexual maturity. After maturity is reached, growth varies widely among individuals of the same age (Fig. 6). 

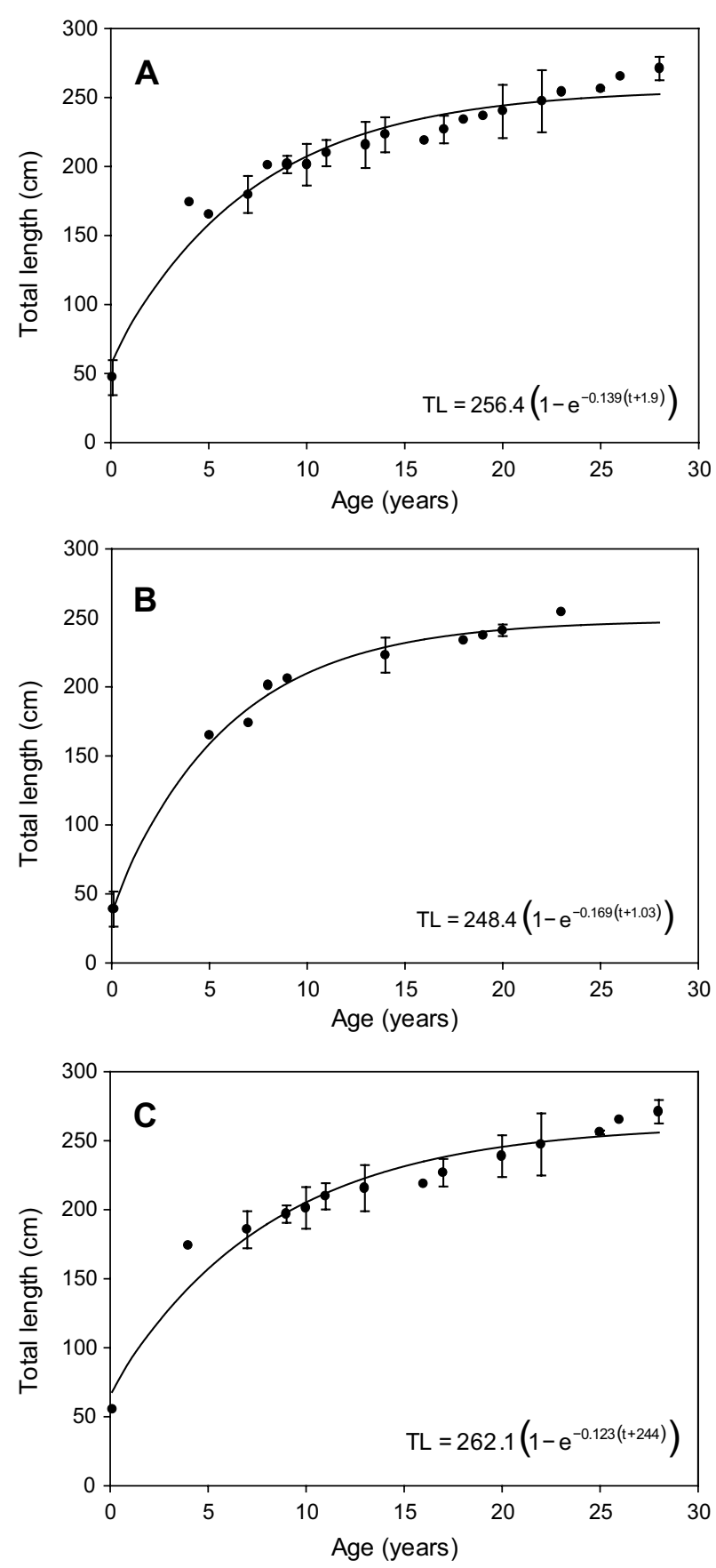

Fig. 5. Von Bertalanffy growth curve of bull shark, Carcharhinus leucas, from the southern Gulf of Mexico. (A) sexes combined; (B) males; (C) females.

\section{Discussion}

The fishery of the bull shark in the southern Gulf of Mexico is focused to individuals in the length range between $201 \mathrm{~cm}$ and $215 \mathrm{~cm} \mathrm{TL}$. $72 \%$ of these organisms were mature sharks.
In this work, we tried several techniques to enhance the visibility of bands in centra. The alizarin red method was used since it proved to be an easy and simple way to give good results, enhancing the rings in vertebrae of C. leucas having $\geq 15$ bands (Fig. 1). Nonetheless, some of the data obtained in this study may have been underestimated because the distance between bands in older sharks was small due to the slow growth rates. Francis and Mulligan (1998), in their study on the age of the school shark Galeorhinus galeus, reported that it was difficult to discern all the growth bands but several other papers on this subject have not reported this limitation (Caselman, 1983; Casey et al., 1983; Schwartz, 1983; Cailliet et al., 1985; Brown and Gruber, 1988; Casey and Natanson, 1992).

In previous works, the X-ray method was used to enhance growth bands in the blue shark Prionace glauca, the thresher shark Alopias vulpinus, and the shortfin mako Isurus oxyrinchus (Caillet et al., 1983, Yudin and Cailliet, 1990). In our case, this technique was not useful and additional technical work is needed to improve exposure times of the X-rays.

An isometric relationship between centrum growth and total length was found as seen in other shark species (Cailliet et al., 1983; Gruber and Stout, 1983; Pratt and Casey, 1983).

Marginal increment analysis of annuli demonstrated that a growth band, consisting of one calcified opaque zone and one translucent zone, is formed with an annual periodicity. Factors that mediate the differential rate of calcium deposition in elasmobranch centra are not known. Changes in temperature and diet (Stevens, 1975), and stress-related activities such as migration (Pratt and Casey, 1983) have been suggested.

Our results show that females of C. leucas in the southern Gulf of Mexico reach 28 years of age, while males attain age 23 , attaining sizes of $271 \pm 8.5 \mathrm{~cm}$ TL and $254 \mathrm{~cm} \mathrm{TL}$, respectively. Branstetter and Stiles (1987), in the northern Gulf, found that the oldest female of this species was 24.2 years $(268 \mathrm{~cm} \mathrm{TL})$, while the oldest male was 21.3 years $(245 \mathrm{~cm} \mathrm{TL})$.

The $k$ estimates of the von Bertalanffy growth model were 0.12 per year for females, and 0.16 per year for males. Branstetter and Stiles (1987) estimated for the northern Gulf of Mexico population that $k=0.076$ per year. Typical values for $k$ in various species of carcharinids fall in the range 0.05-0.2 (Simpfendorfer, 1993). Due to the paucity of samples in the $0-5$ age group, this rate may 
TABLE 2. Von Bertalanffy estimated growth parameters for bull shark, Carcharhinus leucas. Standard error (SE), Coefficient of variation (CV) in percent, and sample size $(n)$, are shown.

\begin{tabular}{lccc}
\hline \hline & Females & Males & Combined sexes \\
\hline$L_{\infty}$ & 262.1 & 248.4 & 256.4 \\
$\mathrm{SE}$ & 8.78 & 5.02 & 6.49 \\
$\mathrm{CV}(\%)$ & 0.03 & 0.02 & 0.02 \\
$k$ & 0.1235 & 0.1692 & 0.1397 \\
$\mathrm{SE}$ & 0.02 & 0.01 & 0.02 \\
$\mathrm{CV}(\%)$ & 0.15 & 0.09 & 0.12 \\
$t_{o}$ & -2.44 & -1.03 & -1.935 \\
$\mathrm{SE}$ & 0.74 & 0.24 & 0.56 \\
$\mathrm{CV}(\%)$ & -0.30 & -0.23 & -0.29 \\
$n$ & & & 54 \\
\hline
\end{tabular}

TABLE 3. Hotelling's $T^{2}$ test (Bernard, 1981) for bull shark, Carcharhinus leucas.

\begin{tabular}{|c|c|c|c|}
\hline \multicolumn{4}{|c|}{$T^{2}=298.345$} \\
\hline $\begin{array}{l}\text { Growth } \\
\text { parameters }\end{array}$ & $\begin{array}{c}\text { Critical } \\
\text { values }\end{array}$ & $\begin{array}{c}\text { Confidence } \\
\text { intervals }\end{array}$ & $F_{o}$ values \\
\hline$L_{\infty}$ & -13.7 & -13.36 a -14.03 & 493.42 \\
\hline$k$ & 0.0457 & 0.38 a -0.29 & 1.80 \\
\hline$t_{o}$ & 1.41 & 1.74 a 1.075 & 0.049 \\
\hline
\end{tabular}

be an overestimate. Most carcharhinid species studied to date have been found to have slow growth rates and to mature after several years (Thorson and Lacy, 1982; Schwartz, 1983; Simpfendorfer, 1993).

According to our data, age at maturity of C. leucas in the southern Gulf of Mexico was 9-10 years. Branstetter and Stiles (1987) found 14-15 years for males and $18+$ years for females of the same species inhabiting the northern Gulf of Mexico. Since biological parameters of this species vary according to different localities, in Table 4 we present a summary of available information.

The fishing pressure due to increasing commercial exploitation of Carcharhinus leucas in the southern Gulf of Mexico is likely to reduce the abundance of this species as a consequence of its relatively low growth rate and late maturity. As pointed out by Branstetter and Stiles (1987), the combination of these $K$-selected characteristics must be taken into account to regulate the fishery of the bull shark, if we consider that life history pattern of elasmobranchs make this group more vulnerable to over fishing because they have slow growth, large adult size, and late reproduction (Hoening and Gruber, 1990).

\section{Acknowledgements}

This research formed part of a dissertation prepared by the senior author for masters thesis at the National Autonomous University of Mexico, on a scholarship from

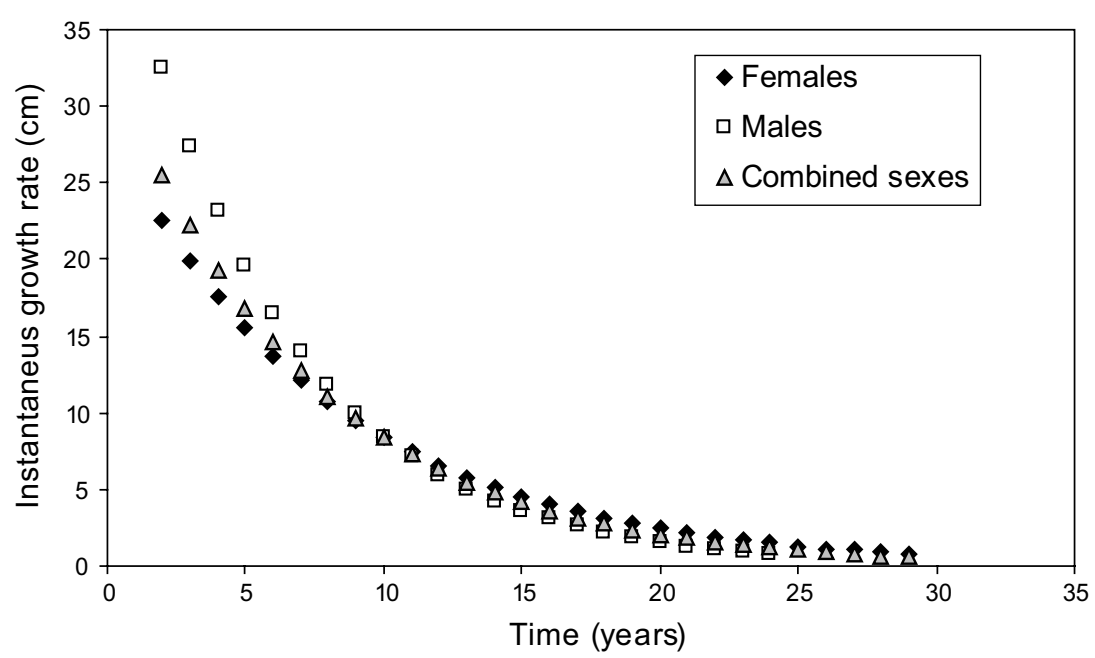

Fig. 6. Instantaneous growth rate of bull shark, Carcharhinus leucas, from the southern Gulf of Mexico. 
TABLE 4. Information on the biology of the bull shark, Carcharhinus leucas.

\begin{tabular}{|c|c|c|c|c|c|c|}
\hline & $\begin{array}{l}\text { Branstetter } \\
\quad(1981)\end{array}$ & $\begin{array}{l}\text { Castro } \\
(1983)\end{array}$ & $\begin{array}{c}\text { Compagno } \\
(1984)\end{array}$ & $\begin{array}{l}\text { Snelson et al. } \\
\text { (1984) }\end{array}$ & $\begin{array}{c}\text { Branstetter and } \\
\text { Stiles (1987) }\end{array}$ & $\begin{array}{l}\text { Rodriquez de la Cruz } \\
\text { et al. (1996) }\end{array}$ \\
\hline $\begin{array}{l}\text { Average total } \\
\text { length }(\mathrm{cm})\end{array}$ & NA & $\begin{array}{l}F=240 \\
M=225\end{array}$ & NA & NA & $\begin{array}{l}F=242-268 \\
M=213-245\end{array}$ & 206.2 \\
\hline $\begin{array}{l}\text { Maximum length } \\
\quad(\mathrm{cm})\end{array}$ & NA & 350 & 340 & NA & $\begin{array}{l}F=268 \\
M=245\end{array}$ & $F=334$ \\
\hline Average weight & NA & $\begin{array}{l}F=130 \\
M=95\end{array}$ & NA & NA & NA & NA \\
\hline $\begin{array}{l}\text { Maximum age } \\
\text { (years) }\end{array}$ & & & 14 & & $\begin{array}{l}F=24 \\
M=21\end{array}$ & \\
\hline $\begin{array}{l}\text { Length-at-maturity } \\
\qquad(\mathrm{cm})\end{array}$ & $\begin{array}{l}F=228 \\
M=217\end{array}$ & 200 & 250 & $F=249$ & $\begin{array}{c}\mathrm{F}=>225 \\
M=210-220\end{array}$ & $\begin{array}{c}F=204 \\
M=190-200\end{array}$ \\
\hline $\begin{array}{l}\text { Age-at-maturity } \\
\text { (years) }\end{array}$ & & & 6 & & $\begin{array}{c}F=18+ \\
M=14-15\end{array}$ & \\
\hline $\begin{array}{l}\text { Gestation time } \\
\text { (month) }\end{array}$ & NA & $10-11$ & $10-11$ & NA & $10-11$ & $10-11$ \\
\hline Time of birth & April-May & April-June & Spring-Summer & May-June & June-August & May-June \\
\hline Pup size (cm) & 75 & 75 & $56-81$ & $60-80$ & 75 & 78 \\
\hline Number of pups & $3-6$ & NA & $1-13$ & NA & NA & $1-22$ \\
\hline Location & $\begin{array}{l}\text { Northern Gulf } \\
\text { Of Mexico }\end{array}$ & $\begin{array}{c}\text { North } \\
\text { American }\end{array}$ & $\begin{array}{l}\text { Symposis of } \\
\text { world data }\end{array}$ & $\begin{array}{l}\text { Indian River, } \\
\text { Florida }\end{array}$ & $\begin{array}{l}\text { Northern Gulf } \\
\text { of Mexico }\end{array}$ & $\begin{array}{l}\text { Gulf of } \\
\text { Mexico }\end{array}$ \\
\hline
\end{tabular}

NA: Not available; F: female; M: male.

the Mexican National Council of Science and Technology (CONACYT). We thank Leonardo Castillo, Sherry Heileman, Fernando Márquez, Oscar Sosa, Ramón Bonfil, Susan Smith, David Au and William R. Fouts for their help during the study. Jack Musick and Steve Branstetter served as referees and provided useful comments on earlier revisions of the manuscripts.

\section{References}

BEAMISH, R. J., and D. A. FOURNIER. 1981. A method for comparing the precision of a set of age determinations. Can. J. Fish Aquat. Sci., 38: 982-983.

BERNARD, D. R. 1981. Multivariate analysis as a means of comparing growth in fish. Can. J. Fish Aquat. Sci., 38: 233-236.

BRANSTETTER, S. 1981. Biological notes on the sharks of North Central Gulf of Mexico. Contrib. Mar. Sci., 24: 13-34.
BRANSTETTER, S., and J. D. MCEACHRAN. 1986. Age and growth of four carcharhinids sharks common to the Gulf of Mexico: a Summary Paper. In: Indo-Pacific fish biology: proceedings of the second international conference on Indo Pacific Fishes, Ichthol. Soc. Jpn., Tokio, p. 361-371.

BRANSTETTER, S., and R. STILES. 1987, Age and growth estimates of the bull shark, Carcharhinus leucas from the northern Gulf of Mexico. Environ. Biol. Fish., 20(3): 169-181.

BROWN, C. A., and S. H. GRUBER. 1988. Age and assessment of the lemon shark, Negaprion brevirostris using tetracycline validated vertebral centra. Copeia 3: 747-753.

CAILLIET, G. M., L. K. MARTIN, D. KUSHER, P. WOLF, and B. A. WELDEN. 1983. Techniques for enhancing vertebral bands in age estimation of California elasmobranchs. In: Proceedings of the international workshop on age determination of oceanic pelagic fishes: tunas, billfishes, and sharks. E. D. Prince and L. M. Pulos (eds.). U.S. Dep. Commer. NOAA, Tech. Rep., NMFS 8: 157-165. 
CAILLIET, G. M., L. J. NATANSON, B. A. WELDEN, and D. A. EBERT, 1985. Preliminary studies on the age and growth of the white shark, Carcharadon carcharias, using vertebral bands. Memoirs of the Southern California Academy of Sci., 9: 49-60.

CASELMAN, J. M. 1983. Age and growth assessment of fish from their calcified structures techniques and tools. In: Elasmobranchs as living resources: advances in the biology, ecology, systematics, and status of the fisheries. H. L. Pratt, Jr., S. H. Gruber, and T. Taniuchi (eds.). U. S. Dep. Commer. NOAA, Tech. Rep., NMFS 90: 1-17.

CASEY, J. G.; H. L. PRATT, Jr., and E. STILLWELL. 1983. Age and growth of the sandbar shark, Carcharhinus plumbeus, from the western North Atlantic. In: Elasmobranchs as living resources: advances in the biology, ecology, systematics, and status of the fisheries. H. L. Pratt, Jr., S. H. Gruber, and T. Taniuchi (eds.). U. S. Dep. Commer. NOAA, Tech. Rep., NMFS 90: 189-204.

CASEY, J. G., and L. J. NATANSON. 1992. Revised estimates of age and growth of the sandbar shark (Carcharhinus plumbeus) from the western North Atlantic. Can. J. Fish Aquat. Sci., 49: 1474-1477.

CASTRO, J. I. 1983. The Sharks of North American Waters. Texas University Press. USA., $180 \mathrm{p}$.

CHEN, C. T., T. C. LEU, S. J. JOUNG, and N. C. LO. 1990. Age and growth of the scalloped hammerhead, Sphyrna lewini, in Northeastern Taiwan waters. Pacific Sci., 44(2): 156-170.

COMPAGNO, L. J. V. 1984. FAO Species Catalog Vol 4: Sharks of the World. An annotated and illustrated of sharks species know to date. Part 1 and 2. FAO Fish Synopsis, 125: $655 \mathrm{p}$.

FRANCIS, M. P., and K. P. MULLIGAN. 1998. Age and growth of New Zealand school shark, Galeorhinus galeus. NZ J. Mar. Freshw. Res., 32(3): 427-440.

GALLUCI, V.F., S. B. SAILA, D. J. GUSTAFSON, and B. J. ROTHSCHILD. 1996. Stock Assessment. Quantitative methods and application for small-scale fisheries. Lewis Publishers, USA, $527 \mathrm{p}$.

GRUBER, S. H., and R. G. STOUT. 1983. Biological materials for the study of age and growth in a tropical marine elasmobranch, the lemon shark, Negaprion brevirostris (Poey). In: Proceedings of the international workshop on age determination of oceanic pelagic fishes: tunas, billfishes and sharks. E. D. Prince, and L. M. Pulos (eds.). U.S. Dep. Commer. NOAA Tech. Rep., NMFS 8: 193-205.

HOENING J. M. and S. H. GRUBER. 1990. Life history patterns in the elasmobranchs: Implications for fisheries management. In: Elasmobranchs as living resources: advances in the biology, ecology, systematics, and the status of fisheries. H. L. Pratt, Jr., S. H. Gruber, and T. Taniuchi (eds.). U.S. Dept. Commer., NOAA Tech. Rep., NMFS 90: 1-16.

KILLAM, K. A., and G. R. PARSONS. 1989. Age and growth of the blacktip shark, Carcharhinus limbatus near Tampa Bay, Florida. Fish. Bull., 87: 845-857.
KWANG-MING, L., C. PO-JEN, and C. CHE-TSUNG. 1998. Age and growth estimates of the bigeye thresher shark, Alopias superciliosus, in northeastern Taiwan waters. Fish. Bull., 96: 482-491.

PRAGER, M. N., S. B. SAILA, and C. W. RECSIEK. 1987. FISHPARM: a computer program for parameter estimation of nonlinear models in fishery science. Dep. Oceanogr. Old Dominion University of Norfolk, U. A. Tech. Rep., 87(10): 1-37.

PRATT. H. L. Jr., and J. G. CASEY. 1983. Age and growth of the shortfin mako, Isurus oxyrinchus, using four methods. Can. J. Fish. Aquat. Sci., 40: 1944-1957.

RODRÍGUEZ DE LA CRUZ, C., J. L. CASTILLO-GÉNIZ, and F. MÁRQUEZ-FARÍAS. 1996. Evaluación de la Pesquería de Tiburón en el Golfo de México. Consejo Nacional de Ciencia y Tecnología. Informe final del proyecto de Investigación 116002-5-1314N9206, 199 p.

SCHWARTZ, F. J. 1983. Shark ageing methods and age estimation of scalloped hammerhead, Sphyrna lewini and dusky, Carcharhinus obscurus sharks based on vertebral ring counts. In: Proceedings of the international workshop on age determination of oceanic pelagic fishes: tunas, billfishes and sharks. E. D. Prince, and L.M. Pulos (eds). U.S. Dep. Commer. NOAA Tech. Rep., NMFS 8: 167-174.

SIMPFENDORFER, C. A. 1993. Age and growth of the Australian sharpnose shark, Rhizoprionodon taylori, from north Queensland, Australia. Environ. Biol. Fish., 36: $233-241$.

SNELSON, F. F., J. TIMOTHY, J. MULLIGAN, and S. H. WILLIAMS. 1984. Food habits occurrence and population structure of the bull shark, Carcharhinus leucas in Florida Coastal Lagoons. Bull. Mar. Sci., 34(1): 71-80.

STEVENS, J. D. 1975. Vertebral rings as a means of age determination in the blue shark (Prionace glauca L.). J. Mar. Biol. Assoc. U.K., 3(55): 657-665.

THORSON, T. B., D. E. WATSON, and C. M. COWAN. 1966. The status of the freshwater shark of Lake Nicaragua. Copeia, 3: 385-402.

THORSON, T. B. 1971. Movement of bull shark, Carcharhinus leucas, between Caribbean Sea and Lake Nicaragua demonstrated by tagging. Copeia, 1: 336-338.

THORSON, T. B. 1972. The status of the bull shark, Carcharhinus leucas in the Amazon River. Copeia, 3: 601-605.

THORSON, T. B., and E. J. LACY, Jr. 1982. Age, growth rates and longevity of Carcharhinus leucas estimated from tagging and vertebral rings. Copeia, 1: 110-116.

WINTNER, S. P., and G. CLIFF. 1996. Age and growth determination of the blacktip shark, Carcharhinus limbatus from the east coast of South Africa. Fish. Bull., 94: 135-144.

YUDIN, K. G., and G. M. CAILLIET. 1990. Age and growth of the gray smoothhound, Mustelus californicus and the brown smoothhound, Mustelus henlei, sharks from Central California. Copeia, 1: 191-204.

ZAR, J. H. 1999. Biostatistical Analysis. Fourth edition. Prentice Hall. USA, 663 p. 